\title{
Creating a positive elementary school climate based on cooperation between the form teacher, headmaster and social pedagogue
}

\section{Lucie Blaštíková iD}

\section{Contact}

Tomas Bata University in Zlín Faculty of Humanities Štefánikova 5670

76001 Zlín

blastikova@utb.cz

$\square$ Correspondence: blastikova@utb.cz

Copyright $(02021$ by the author and publisher, TBU in Zlín.

This work is licensed under the Creative Commons Attribution International License (CC BY).

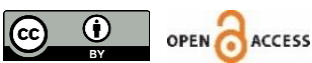

\begin{abstract}
The empirical study presents the dimension of positive school climate using illustrative models that reflect the statements of the participants of a qualitatively oriented research survey including semi-structured interviews. The theoretical introduction deals with the definition of key concepts and briefly outlines selected domestic and foreign models of positive climate. Based on the interviews, it was found that interpersonal relationships are important for all actors who create the school climate and influence mutual cooperation. Teachers point to the need for a fair approach to all pupils; the school principal pays attention to physical and social-emotional security; and the social educator seeks to work with groups of pupils as well as provide counselling for teachers. The aim is to link all these processes in the interest of a positive school climate. For this reason, it is necessary to focus on the mutual cooperation of selected actors who affect the school climate and to reveal possible shortcomings in the field of their cooperation. These shortcomings include, in particular, little involvement, disinterest, lack of concern or poor school philosophy.
\end{abstract}

Keywords: cooperation, elementary school, form teacher, headmaster, school climate, social pedagogue

\section{Spolupráce třídního učitele, ředitele a sociálního pedagoga při vytváření pozitivního klimatu v základní škole}

\begin{abstract}
Abstrakt: Studie představuje dimenze pozitivního klimatu školy $\checkmark$ jednotlivých modelech, které odrážejí výpovědi respondentů, které byly získány na základě kvalitativně orientovaného výzkumného šetření $v$ rámci polostrukturovaných rozhovorů. Teoretický úvod se věnuje vymezení stěžejních pojmů a stručně nastiňuje vybrané tuzemské i zahraniční modely pozitivního klimatu. Na základě rozhovorů bylo zjištěno, že mezilidské vztahy jsou důležité pro všechny činitele, kteří klima školy vytvárí a vzájemnou spoluprací ovlivňují. Učitelé poukazují na nutnost spravedlivého př́stupu ke všem žákům, ředitel školy věnuje pozornost fyzickému a sociálně-emočnímu bezpečí a sociální pedagog se snaží o práci s kolektivem žáků, ale i o poradenství pro učitele. Cílem je propojit všechny tyto procesy $v$ zájmu pozitivního klimatu školy. $Z$ tohoto důvodu je nutné soustredit se
\end{abstract}


na vzájemnou spolupráci vybraných činitelů klimatu školy a odhalit možné nedostatky $v$ oblasti jejich kooperace. Mezi tyto nedostatky patří zejména malá angažovanost, nezájem, obavy nebo filozofie školy.

Klíčová slova: klima školy, ředitel, třídní učitel, sociální pedagog, základní škola, spolupráce, model

\section{Introduction}

The issue of school climate and other variations of climate (school climate, teaching climate, faculty climate) is already well known in the field of educational research, particularly in the context of the identification of the current and preferred climate (Lašek, 2012) or evaluation of the school climate by agents (parents, teachers, pupils) (Grecmanová, 2008). The concept of climate in other countries is broader and more sophisticated and the research is more variable, and it is not restricted only to questionnaire surveys. Moreover, there are obvious efforts to intervene in a school's negative climate (Phillips \& Rowley, 2016). They also monitor the relationship between pupil and teacher, which aims to monitor the relationship between class and teacher (Veiskarami, Ghadampour, \& Mottaghinia, 2017). This study aims to introduce qualitative research into the dimensions of a positive climate according to selected school agents. ${ }^{1}$ Subsequently, it analyses the nature of the cooperation between these agents to create a positive school climate. The selected agents are teachers, pupils and school management - the headmaster and his deputy, as well as parents and administrative and operational staff. Not only school employees, but also other external agencies cooperating with school - statutory authorities, the social-legal child protection authority, the police of the Czech Republic, etc. - have an impact on the climate. Teachers, pupils and parents are most often selected for climate research (Grecmanová, Dopita, Poláchová Vaštatková, \& Skopalová, 2012; Pinkas \& Bulić, 2017; "Shared leadership," 2018). The questionnaires are most often used not only in the Czech but also foreign pedagogical field (Dalbert \& Stöber, 2002; Edgren \& Hiffling, 2010; Tapia \& Heredia, 2008). Certain members of the school environment were selected for research purposes. From management, the position of headmaster was selected; therefore, he is an important factor in the school climate (Adams, Ware, Miskell, \& Forsyth, 2016; Grecmanová, 2008). Other important factors in school climate are form teachers, who influence the climate in their classrooms. Based on experience abroad from Slovakia, Germany, Poland and Finland (Cameron \& Moss, 2011; Kraus, 2014), social pedagogue, a position that is still developing and seeking its place in the Czech school environment, was also chosen for research as a member of a school counselling centre. Cooperation of selected members is briefly outlined within the theoretical background. The main concepts and selected theories will be presented, followed by the definition of a positive school climate, its dimensions and areas according to the National School Climate Center ("Shared leadership," 2018).

\section{Positive school climate}

There is a terminological inconsistency in the Czech pedagogical environment, thus different terms are often used, like the 'good climate', 'supportive climate' (Lašek, 2001), 'favourable climate' (Grecmanová, 2008) or 'open climate' of the school (Mareš \& Čáp, 2007). In the Czech environment, a positive school climate is considered to be an environment in which a cooperative and healthy competitive atmosphere is encouraged (Hrabal, 2002). The National Center on Safe Supportive Learning Environments (2018) conceives a positive climate as a phenomenon associated with the pupils' school achievements, as the climate also affects educational attainment. Understanding the

1 The research is set at the second stage of elementary school (which in the Czech educational system are grades 6-9). Selected agents for this research are the headmaster, form teacher and social pedagogue. 
climate framework can help teachers identify the key areas they will focus on to create favourable and safe climatic conditions in school. A sustainable and positive school climate helps with the development of young people and with teaching them important knowledge, so they will be able to live a productive and satisfying life in a democratic society. This climate includes norms, values and expectations forwarded by people who have acted in the social sphere and feel emotionally and physically safe. Everyone is involved and respected. Students and pupils, families and educators cooperate to develop and contribute to the shared school vision (Cohen, McCabe, Michelli, \& Pickeral, 2009).

The model of a positive school climate according to the National School Climate Center ("Shared leadership," 2018), where the term sustainable climate in connection with a positive climate is used, is presented further; moreover, this model is an inspiration for qualitative research and its conclusions. The model is presented in Table 1.

Table 1

Areas and dimensions of a positive school climate

\begin{tabular}{ll}
\hline Areas & Dimensions \\
\hline Safety & Rules and Norms \\
& Physical Security \\
& Social-Emotional Security \\
& Support for Learning \\
Teaching and Learning & Social and Civic Learning \\
& Respect for Diversity \\
Interpersonal Relationships & Social Support-Adults \\
& Social Support-Students \\
Institutional Environment & School Connectedness/Engagement \\
& Physical Surroundings \\
Staff Only & Leadership \\
& Professional Relationships \\
\hline & Source: National School Climate Center ("Shared leadership," 2018).
\end{tabular}

The presented model (Table 1) contains five areas of positive school climate, which are then specified into dimensions. The National School Climate Center has a long-term focus on positive climate content, which it seeks to research and verify by collaboration with the school or at various research levels. For this reason, the positive climate model has been increased by one area, namely All Populations, which is particularly concerned with protecting pupils from social networks. Rudasill, Snyder, Levinson and Adelson (2017) are among the authors who have devoted their work to a positive school climate. The research team presented the Systems model of school climate (Rudasill et al., 2017) based on the analysis of several selected theories. It was Anderson's model from 1982 in which emphasis was placed on adherence to rules within the school (Anderson, 1982). Furthermore, the authors analysed the model of Hoy and Hannum (1997), where closer cooperation with parents and a higher degree of collegiate behaviour were already foreseen. The model of Creemers and Rezzigt (1999) also addresses the teacher-pupil relationship. However, the above-mentioned Systems model of school climate is primarily based on the work of Cohen et al. (2009) and Thapa, Cohen, Guffey, and Higgins-D'Alessandro (2013), where the emphasis is put on ensuring safety during teaching, the teacher-pupil relationship and relationships among pupils. The National Center on Safe Supportive Learning Environments (2018) presents a school climate model that addresses safety and support in the school environment and focuses on involvement in specific parts of the model. Emphasis is placed on the relationship between teacher and pupil, which is essential for a positive climate. Respect for diversity is also part of the model and is related to respect for other racial and religious affiliations. Furthermore, it deals with participation, i.e. participation in school life, which means engaging in those activities that can positively influence the climate (extracurricular activities of children, trips, etc.). The model also 
includes emotional and physical security, particularly situations where the pupil does not have to be afraid of teachers and classmates. The safety part also includes the issue of substance abuse in the context of risky behaviour. The authors devoted the last part of the model to the environment, namely the academic environment of the teachers. Furthermore, it mentions discipline, where there is room for rules which should be introduced to pupils in advance.

Other interesting models are presented, for example, by Lane-Garon, Yergat, and Kralowec (2012), where they try to carry on the improvement of the current school climate. Townsend et al. (2017) talk about a positive climate, focusing on non-stigmatizing environments. The common feature of all these models is the pupils' safety, which cannot be clearly described. Safety should be seen as a nonthreatening environment in the classroom and in the school, in which all agents of the school climate should participate.

\section{Cooperation of selected agents}

Píšová (2004) states that for the cooperation of teachers, it is important to maintain a favourable social climate in which open and friendly communication, trust, and willingness to listen to each other and help is present. In the absence of a favourable climate and mutual collegiality, its artificial enforcement is an obstacle to cooperation between teachers (Dewitt, 2018). Harpe developed a model of cooperation that includes four components. These include working time collaborations, setting and adhering to common goals, a results orientation and mutual support (Harpe, 2016). Statistically significant differences were found during the evaluation of cooperation among teachers and pupils' school results, which could primarily depend on the cooperation of teachers. The study stated that one uncooperative teacher could disrupt the whole concept of school functioning.

The study not only discusses cooperation between teachers, but also focuses on the cooperation of selected agents of the school climate, namely form teacher, headmaster and social pedagogue. All three agents are briefly described below. Hermochová (2009) states that in the current school system, form teachers are primarily expected to fulfil coordination and integration functions. On the contrary, the work of a form teacher is discussed by many authors (e.g. Bréda, Čapek, Dandová, \& Kendíková, 2017). The form teacher plays an irreplaceable role in a pupil's life and should have a wide range of competences and skills. Gillernová and Krejčová (2012) pay particular attention to the social skills of the teacher, meaning the importance of respecting the personality of the pupil, colleagues, and parents. Furthermore, the authors mention the authenticity of teachers' speeches, empathy, listening, differentiation of experiences and feelings from reflections, judgments and opinions about oneself and others. The teacher must be able to praise and to be a conflict manager (Dicken, 2013). "The headmaster is the principal and irreplaceable person of each school, responsible for the school's development and quality results" (Trojan, Tureckiová, \& Trunda, 2015, p. 30). There is a growing demand for the position of headmaster in connection to the legal subjectivity of schools, a change in the state organization and many changes in the school management system (Dédina \& Odcházel, 2007). Kalnický, Malčík, and Uhlař (2012) and Murphy and Louis (2018) include the following among the important processes managed by the headmaster:

- development of the school, climate and relationships;

- maintaining relationships with parents and the public;

- learning and teaching with knowledge exams;

- guidance counselling;

- management and quality control;

- provide support for individual needs including special learning needs;

- structure of curriculum and study programmes. 
According to Grecmanová (2003), the headmaster's characteristics influence a positive school climate, i.e. empathy, 'non-authoritative' genuine behaviour, acceptance of others, self-identity, and activity (Oyetunji, 2010). The position of social pedagogue in elementary school is somewhat less widespread. Based on an analysis of the current situation, there are about 32 public elementary schools (information from the school year 2017/2018) where the social pedagogue acts as a member of school counselling and does not have other functions such as teacher assistant, educator, etc. Kraus defines a social pedagogue as follows:

"A social pedagogue, on the professional level, manages and organizes the educational process and affects the subject of the education on two levels: integration - the social pedagogue focuses on persons (clients) who need professional help and support (people in crisis, under a psychological, social or psychosocial threat, who are becoming an obstacle for their surroundings); and development - the social pedagogue supports and consolidates desirable personality development" (Kraus, 2014, p. 198).

Cameron and Moss (2011) argue that the role of the social pedagogue can be understood not only in a pedagogical context but also more comprehensively as care and education on behalf of society. As examples, the authors mention leisure activities, early childhood care and other options of education with some social overlap. According to Stephens, the activities of a social pedagogue are different and have various descriptions. Examples include childcare, educational psychology, centres for substance abuse, personal assistance and community work (Stephens, 2013). The fact should be stressed that Czech legislation does not recognise a social pedagogue as a pedagogical worker. However, the Association of Educators in Social Pedagogy helped to open up Act No. 563/2004 Coll., on pedagogical staff, as amended ("Act No. 563/2004," 2019), with social pedagogues implemented within it. Considering the future conclusions of the legislative process, the position of the social pedagogue within Czech primary schools may undergo significant transformation. This is not to say, however, that social pedagogues do not already work in Czech primary schools. We can already find many schools which employ social pedagogues within the school counselling service. Their job descriptions correspond to the job description issued by the Association of Educators in Social Pedagogy ("Association of Educators," 2020). One area of focus is in promoting a positive climate within the school and classroom, in order to secure working relationships between individual school climate agents.

All these agents are connected by the school environment, in which they strive to create a positive school climate. Among other things, this research requires the definition of a school as a social institution.

"The school fulfils several functions (an activity with a specific purpose, task, goal and mission) that express how useful it is for society. The functions of the school justify its existence in society, express the meaning of the school's activities and its relationship to the needs of society, and determine its position among other institutions. Schools are established on the initiative of the state and certain groups within society (private founders, churches, etc.). The relationship between society and the school reflects the general objectives that the school should pursue through its activities" (Walterová \& Greger, 2009, p. 10).

The content of basic education is a part of the Framework Educational Programme for Basic Education (“Act No. 561/2004," 2019). 


\section{$4 \quad$ Materials and methods}

This study aims to identify and describe the positive climate dimensions created by the headmaster, form teacher and social pedagogue ${ }^{2}$ and characterize the cooperation to create a positive climate between headmaster, form teacher of the second stage of elementary schools and social pedagogue, based on existing models of positive climate. ${ }^{3}$

A qualitative research strategy with the design of a case study and a semi-structured interview method was used to achieve the research goal. Specific selection criteria were set for the selection of the research sample. It was important for the sample that the public elementary school has a social pedagogue position. Based on my survey of the current situation, 32 elementary schools were found. Another criterion for the research was that the school have grades $6-9$, with at least one class from each grade. A total of 25 elementary schools were addressed. Based on the feedback, four more schools were contacted. One elementary school was chosen, as it employs a social pedagogue fulltime. This elementary school has a second stage, with 224 pupils educated in nine classes. Altogether, seven form teachers took part in the research. Two other form teachers refused to take part in the research because of their workload. Two other agents selected for the research were the headmaster and the social pedagogue. Semi-structured interviews were used to determine the content and importance of the school climate according to selected agents, in the context of the school climate dimensions according to the National School Climate Center (see above). At the same time, the questions in the interview focused on the area of cooperation between selected agents in the context of the school climate. The interview for the social pedagogue consisted of 28 questions and covered six areas that focus on field competence, relationships and collaboration with teachers, pupils and school management, the concept of the school, and the area related to climate. The interview with the headmaster had 33 questions covering similar areas as those for the social pedagogue. Interviews with form teachers were designed the same way. The interview with the headmaster took 50 minutes, and the one with the social pedagogue lasted 56 minutes. Interviews with form teachers ranged from 15 to 45 minutes. Teachers had worked at the selected elementary school in the range of 3 to 20 years. All interviews were recorded ${ }^{4}$ and subsequently transcribed and coded.

The method of data analysis was open coding, i.e. work with data snippets, codes and categories. Based on the interviews with form teachers, categories were created on the basis of codes from respondents' statements. ${ }^{5}$ The interview with the headmaster, who has been in the education sector for 30 years and is in the position for a fifth year, was coded the same way. ${ }^{6}$ The interview with the social pedagogue, who has been working in the selected school for three years, was analysed in the same way. ${ }^{7}$ At the same time, there was a detailed study of one case that was defined by the case study design (Stake, 2005; Švaříček \& Šed'ová, 2007).

Cmap Tools was chosen for better illustration of the individual dimension of positive climate according to the selected factors. Individual models result from the created codes and categories and adhere to

2 The research question is: What are the dimensions of a positive climate according to the headmaster, form teachers and social pedagogue?

3 The research question is: What is the character of the cooperation between the form teacher, the headmaster and the social pedagogue based on the models of positive climate?

4 Respondent agreed to this method.

5 Examples of the categories: What belongs to the school climate?; Rules, rules and rules again...; Positive climate = the approach towards everyone; I want a positive school climate, so what should I do?; etc.

6 Examples of the categories: A school counselor and social pedagogue are our advantages!; Form teacher - some cannot be changed; I cannot feel the positive climate; To improve the school climate... yes, but how... that is hard!; etc.

7 Examples of the categories: Small problem - job duties; Form teachers are hard to crack; Positive climate? Yes! But we need to go to classes; The headmaster is support; etc. 
the model structure according to the National School Climate Center ("Shared leadership," 2018). The presented areas are the same as in the sample model, yet the specific dimensions are based on the categories and codes that emerged from the specific interviews. For this reason, three models of positive climate according to the selected agents (respondents) are presented, as well as a model that characterizes cooperation in creating a positive school climate. The created models are supplemented by respondents' statements and conclusions of other research surveys.

The conclusions that will be presented below cannot be generalized - this is not the aim of the text. The intention is to understand a particular school in terms of creating a positive school climate through selected agents.

\section{The model-expressed results and discussion}

The below-detailed models were created on the basis of categories and codes. Examples of individual categories, codes and respondent testimony are given in the summary table for each model. Tables with relevant categories, codes and statements of respondents are given in the annexes to this article (Supplementary Table 1, 2, and 3).

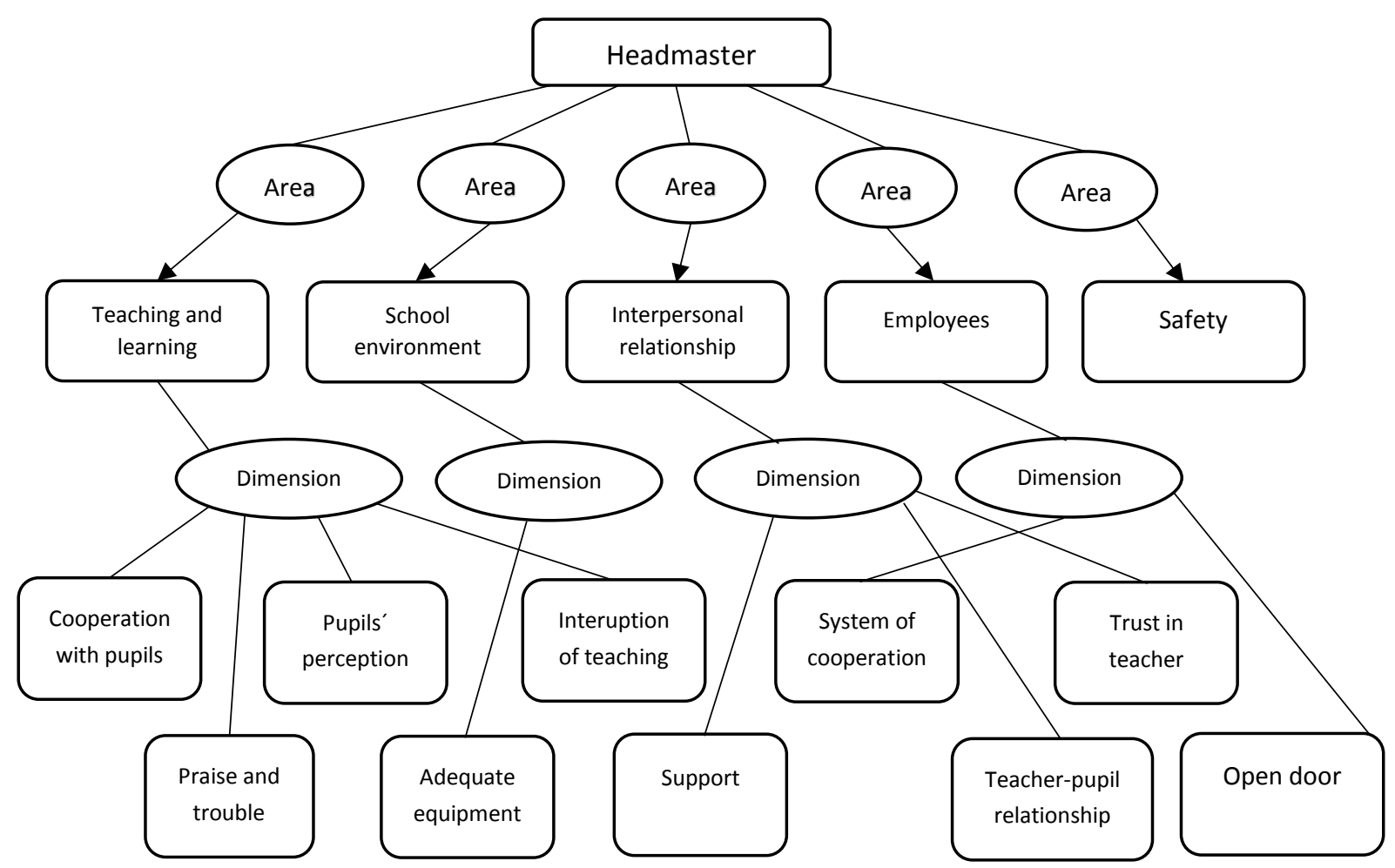

Figure 1 Model of a positive school climate according to the headmaster

Source: Author.

Specific dimensions (codes based on the open coding of the interview with the headmaster) were included in the areas from the positive climate model of the National School Climate Council ("The 13 dimensions," 2015). Some dimensions in Figure 1 appear in multiple areas. On the contrary, some areas remain content-free, i.e. without dimensions, as respondents did not comment on the area or spoke too briefly. The headmaster mostly focused on teaching and learning (most of the dimensions/codes are a part of this area), where cooperation with pupils, support and trouble, pupils' perception and interruption of teaching have been included. The headmaster perceives teaching as a central part of the educational process which is reflected in the classroom climate (school climate). By cooperation with pupils, it is meant that the headmaster teaches some classes at the second stage. As a headmaster, I usually meet pupils while I am teaching. He also mentioned visiting the classes for 
different reasons. Of course, I also meet pupils when there is some trouble or I come with praise, which is very important. You can't just punish. The headmaster tries to read the mood in the classrooms: At the second stage of the elementary school, pupils are wild, even though the ninth-graders are fine. But other classes have individuals who can influence the whole class. The social aspect, in terms of the interruption dimension, can be considered very important. I can stop teaching and address what is important at that moment. The area of relationships between pupils, their problems and the reason for their inability to focus are considered important in this case. The school environment, another area of the model, is filled with the dimension of adequate equipment. We are well equipped, and we have submitted a project for the modernization of some classrooms. However, we have an old computer room with dying computers... Understandably, the headmaster perceives the material and didactic equipment very strongly. This may be due to worries about sufficient funds and complaints from some teachers.

Interpersonal relationships consist of three dimensions. The first dimension is devoted to support, which partly belongs to the employees area as well. From the position of the headmaster - in the context of interpersonal relationships - this type of support concerns parents and institutions. There is a lack of support for parents and institutions, i.e., the social-legal child protection authority. It was stated in the interview that some measures are not sufficiently monitored and thus, in that case, parents do not consider cooperation with the school to be adequate. Support in the context of employees concerns the opportunities for further education in the form of seminars, courses, etc., along with other activities for the consolidation of teachers. Adaptation courses remain without response. The last area is devoted to safety, but it remains unfulfilled with dimensions. This conclusion does not coincide with the selected models described above; moreover, the safety area in those models is at the forefront. For example, The National Center on Safe Supportive Learning Environments (2018) model involves emotional safety and physical safety, and also focuses on preventing substance use. Based on the established model, it is possible to deduce the current situation at the selected elementary school from the position of the headmaster. This is the model that is expected to change over time and with school development. The headmaster places great emphasis on teaching and learning, and also pays great attention to pupils and their problems. The headmaster expects to create a school climate (and classroom climate) during teaching; however, at the second stage, he does not yet feel a positive school climate.

The model is further described in the context of a positive school climate according to Thapa et al. (2013), who sees the importance in these particular points:

- $\quad$ safety - physical safety, but also social-emotional safety for all participants in school life. As mentioned above, the model of positive school climate does not work with safety dimensions at all. Therefore, it can be concluded that there are no risky manifestations in the school such as bullying or cyberbullying. This fact is also supported by interviews with other respondents. The poor school results of pupils and the parents' lack of interest in cooperation are considered to be the fundamental problems.

- relationships in the school environment - respect for diversity, commitment and social support. Interpersonal relationships play a very important role in the headmaster's model, primarily the teacher-pupil relationship. He believes that their relationship must be filled with trust. The respondent stated that in each class the influence of the form teacher was reflected. He was less concerned with the relationships between pupils.

- learning - social, emotional, ethical and other types of learning. The headmaster perceives this area positively and as being essential for creating a positive school climate. He believes that during the time of teaching, the school climate (and of course classroom climate) can be shaped. This involves not only cognitive goals and the realization of the learning unit's goal but also the setting of effective goals, which are particularly difficult to achieve. The analysed model by Thapa et al. (2013) shows that social and emotional learning is important for pupils. 
- the physical environment of the school. In the context of the environment, the headmaster mentioned adequate equipment. Some classes will undergo the process of improvement and modernization. The headmaster is interested in the physical environment from the perspective of financial support. However, further in the interview, the environment was not mentioned.

- the process of improving one's work. The respondent tries to involve the school in various projects and activities that help the teacher to take a step with a minimal financial burden. However, there is no positive response from the teachers. He spoke rather marginally about the steps he needs to take in his position. Shen et al. (2015) presented research on the teachers' motivation to improve their work. It has been shown that a positive work attitude greatly affects the climate of the teaching staff, which is reflected in the overall school climate.

Thapa et al. (2013) further argue that the negative effects may result from the negative (unfavourable) school climate. This may affect pupils and result in psychological problems or substance abuse.

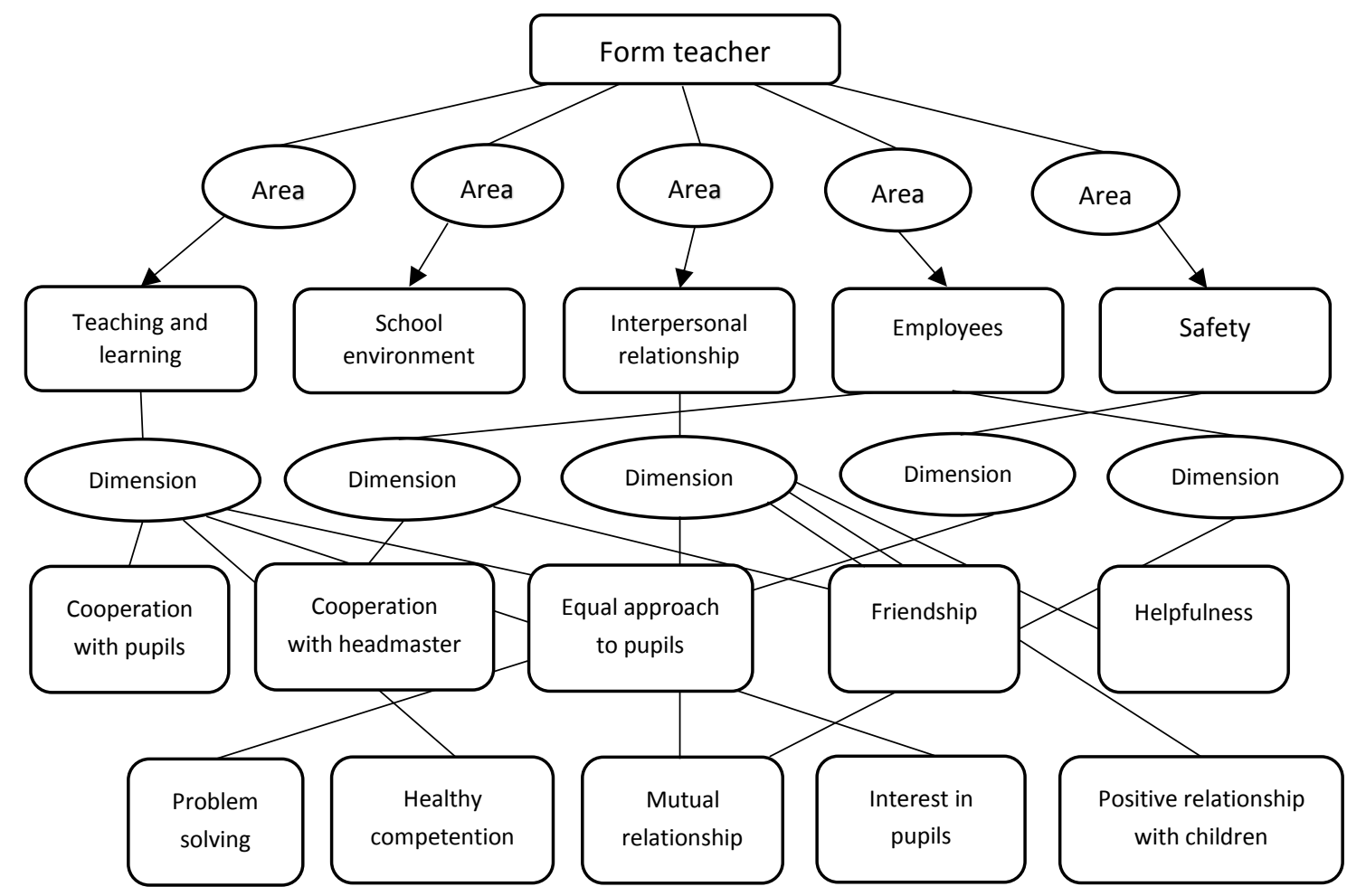

Figure 2 Model of positive school climate according to second-stage form teachers

Source: Author.

The same procedure as in the previous case was followed in developing a school climate model based on interviews with form teachers. Selected areas in Figure 2 are more saturated, as there were seven interviews conducted, and thus more codes were created. The first area, teaching and learning, contains the following dimension - cooperation with pupils, equal approach to pupils, healthy competition and interest in the pupil. More respondents mentioned cooperation with pupils. However, the content of this cooperation was very difficult to define, as teachers could not specify it. In the context of the respondents' statements, it is possible to define it as a certain pupil's participation in teaching (often during the preparation). Teachers evaluate the cooperation of pupils positively. School climate is shaped by ... a fair approach to all, human approach, school trips... Respondents tend to be interested in pupils, respect their opinion and listen to them. Form teachers also strive to establish a trustworthy relationship with pupils. The area of the school environment contains no dimension, yet there are several reasons for that. Form teachers do not deal with the financial aspect of class improvement, and they also do not have to devote much time to the decoration of classrooms, 
corridors or notice boards. Moreover, the teachers did not evaluate the cleanliness of the school in their interviews. Only one respondent evaluated class cleanliness as kept by the pupils. The third area is interpersonal relationships, which include the dimensions of cohesion, friendship, friendliness, mutual relationship and positive relationship with children. Pupils often turn to form teachers to seek relationship advice - relationships between pupils, but also, according to the statement of one respondent, the relationship between teacher and pupil. Another respondent also stated that it is necessary to promote cohesion and friendship among children to achieve a positive climate. At the same time, teachers must take a friendly and fair approach towards children.

The area of employees is filled with the following dimensions - cooperation with the headmaster and mutual relationships. Collaboration with the headmaster mainly includes problem-solving contact ...whenever I need school management to solve a problem. Cooperation with the headmaster also affects the organization of school events or ...production of a concert, deadlines, etc. One respondent stated that the cooperation of the headmaster only applies to his consultation hours. The last area of the model is safety, with the dimension of problem-solving assistance. This dimension mainly includes relationship problems, as already mentioned. In addition, pupils turn to teachers to resolve poor school results and problems with some subjects. Teachers most often use the method of conversation when resolving problems with pupils. From the respondents' statements, it can be deduced that they can evaluate the climate in their classes, and thus they perceive and evaluate the classroom climate more than the overall school climate or the second-stage climate. However, from the semi-structured interview questions and their responses, it can be stated that the school climate is assessed rather negatively, and as being insufficient ...After six months, the climate at the second stage is acceptable. Nevertheless, they perceive the classroom climate (in their classes) to be considerably better, i.e. positive or good ... the classroom climate is quite good.

This conclusion may be caused by the fear of an unfavourable evaluation of one's class and, at the same time, of a negative evaluation of one's work. Classroom teachers can perceive their contribution to the overall second stage of the elementary school climate as significantly smaller and not so important. Grecmanová (2008) states that a positive climate from the teachers' point of view is formed, for example, by the helpfulness of teachers, fair treatment of children, individual support for each pupil, and appropriate motivation of pupils. This was confirmed by the form teachers to be a part of the school's positive climate model. A fair and helpful approach to pupils is stated as being vital. The model shows that teachers place great emphasis on interpersonal relationships, teaching and learning. A study of the importance of interpersonal relationships was conducted by Hamre and Pianta (2009) in the kindergarten environment. They attempted to verify the importance of the pupil-teacher relationship. It was found that a conflicting and negative relationship between teacher and pupil significantly influences the pupil's relationship to further education.

The research showed insufficient results from studying and manifestations of risk on the part of pupils who had a negative relationship with their teacher (Lašek, 2001). The important role of relationships was also appreciated in Quin's research (2017). This cross-sectional study described the content of teacher-pupil relationships. He also verified the importance of these relationships, as the following are crucial for them - psychological engagement, grades (the pupil's school results), regular school attendance and classroom disturbance. The relationship between teacher and pupil is important, but it is not the only one. It is obvious that teaching and learning are a crucial area for teachers, and in foreign surveys (Shen et al., 2015; Warburton, 2017) many terms can be found that relate to this dimension, i.e. motivational and performance climate.

Warburton (2017) perceives the motivational climate positively, as it encourages pupils to continue their work. The second type of climate, defined by the author, is the performance climate, related to competitiveness and competition. Respondents also tend to create healthy competition among pupils. The research of Shen et al. (2015) discusses the motivation of pupils to learn. They focused their attention on the relationship between a pupil's motivation to learn and the burnout syndrome of teachers. The burnout syndrome is a fundamental environmental factor that affects the motivation of 
pupils, the pupils' relationship with the school, and consequently the school climate. Part of the process of learning and teaching involves the pupils' school results. As an example, the respondents consider the pupils' school results as a significant aspect of the school climate, one which has a negative influence on him. However, it is always important to try to determine why his results are bad. Research by Ramsey, Spira, Parisi, and Rebok (2016) points to the inverse relationship between school climate and pupils' school results. Their research showed that the resulting school climate affects the performance of pupils as well as the teachers' work. There is a relationship between the climate and the work results of teachers and pupils.

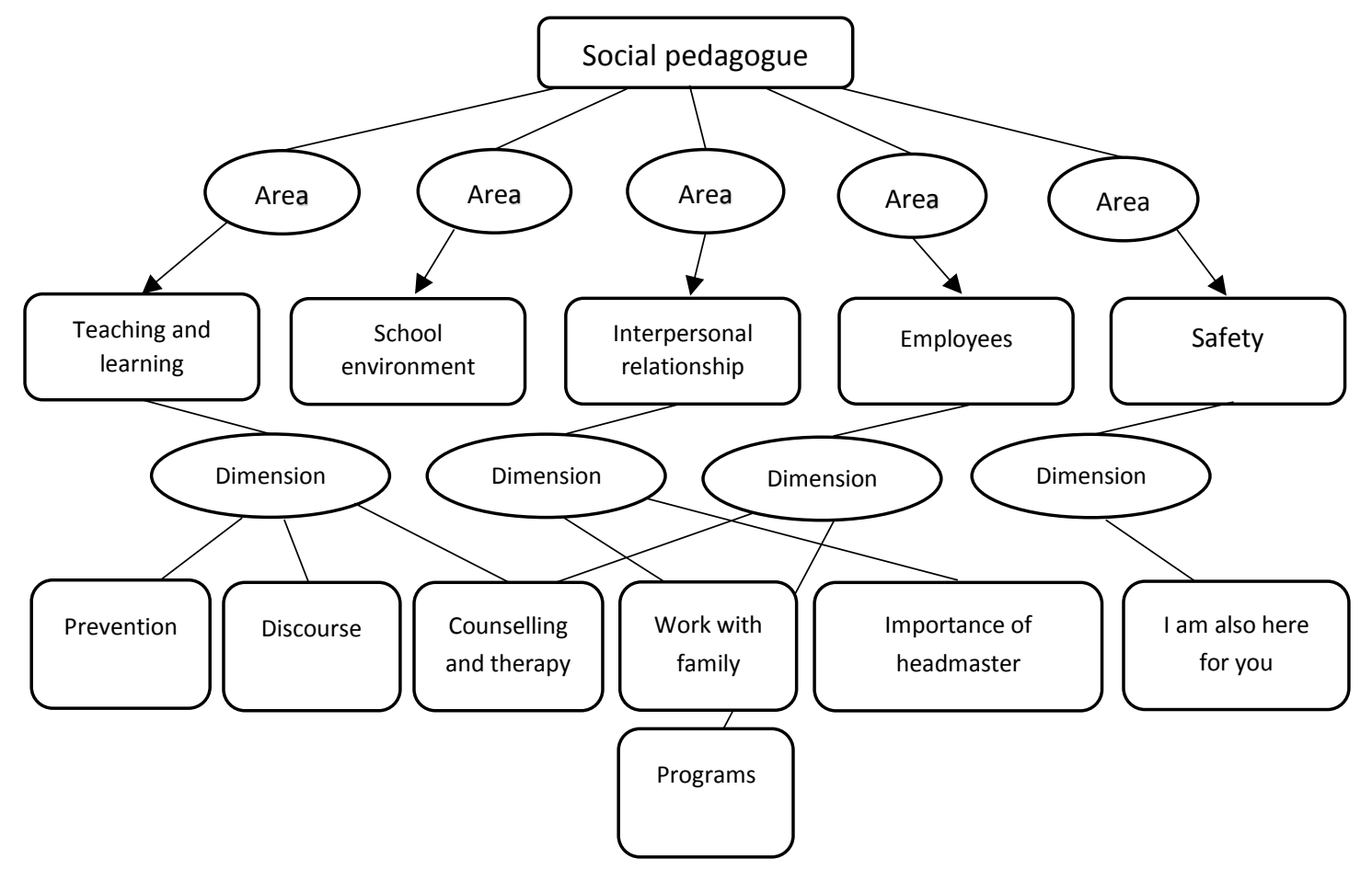

Figure 3 Model of positive school climate according to the social pedagogue

Source: Author.

The social pedagogue is a member of a school counselling centre at the selected elementary school. He works together with the prevention methodologist, educational counsellor, and career counsellor to create a positive school climate. However, based on the statement of the social pedagogue, this task is not easy for various reasons. The areas of the positive school climate model from the National School Climate Center ("Shared leadership," 2018) were used even in this case, but the situation in these areas is more complicated because the social pedagogue is not a teacher. Thus, in the first area in Figure 3 - teaching and learning - the dimension related to the social pedagogue's methods and way of working was integrated. These include prevention, discourse, counselling and therapy, which are the methods most often used by the social pedagogue. The respondent stated that he deals with prevention independently, but also in cooperation with the prevention methodologist. Preventive actions concern lying and the frequent absence of pupils from school. The social pedagogue would like to focus more on ...early-warning signs to uncover forms of risky behaviour...working with class groups... The most common method used by the social pedagogue is a method of discourse which he uses to talk with pupils, as well as teachers. Yet he does not use this method with teachers so often because ...only two colleagues asked for my advice... The social pedagogue, alongside the headmaster and form teachers, is a member of a school committee. Counselling and therapy are a part of the job description of the respondent at the selected elementary school; moreover, he focuses his work on interpersonal relationships, communication, self-knowledge and self-concept, influencing pupils' attitudes and values, and problem-solving, which includes preparing pupils for real-life situations. According to Kraus (2014), along with counselling and fieldwork, the work tasks of a social pedagogue 
have an educational nature. He defines them as a mosaic - unrepeatable and creative in their way, yet not enshrined in Czech legislation. Therefore, school management usually structures the job description of a social pedagogue independently, based on their needs.

As in the case of the form teachers' climate model, the school environment area is not filled with dimensions. This may be due to similar reasons: low engagement regarding school modifications, decorations, etc. However, the respondent sees one thing as part of this area: the absence of his own space, company notebook and mobile phone.

The area of interpersonal relations is filled with these dimensions: working with family and the importance of the headmaster. The following duties are part of the official social pedagogue job description set by the headmaster:

- social pedagogue focuses on working with families and children,

- acts as a mediator between family and school,

- assists with different activities in and out of school, including family activities,

- offers assistance to families who cannot provide good conditions at home for the preparation of pupils.

The social pedagogue knows the family environment of the pupils to a large extent (the individual requirements for the position of social pedagogue correspond to the theoretical part of this study). In Slovakia, the position of social pedagogue is defined by "professional activities in the framework of prevention, intervention and counselling, especially for children and pupils at risk of social-pathological phenomena, socially disadvantaged children, drug-addicted or otherwise disadvantaged pupils, their legal guardians and pedagogical employees." ("Act No. 317/2009 Coll.," § 27, 2019). According to this definition, the position of social pedagogue is aimed at preventing the risky behaviour of children and adolescents.

Hroncová (2016, p. 26) presented a similar definition: "The core competence of a social pedagogue, whether in school or school facilities, must be complex and continuous, as the boundaries between the different types of prevention are constantly moving, and the different types of prevention overlap and complement each other."

The headmaster plays an important role, whether the school management employs a social pedagogue or not. Nevertheless, the respondent expresses a positive opinion on cooperation with the headmaster ...whenever I had a problem or request, he always responded and helped me.

The area of employees with the dimension I am also here for you aims to help not only pupils but also teachers and other school employees. Whether the social pedagogue will be allowed to enter the class is dependent on the will of the form teacher. In this particular case, the teachers are still concerned about their cooperation with the social pedagogue. The last area of safety is filled with the dimension of programmes - preventive programmes, programmes for personal and social development. The respondent is involved in this area, but less than he would like to be, or would be able to manage. The social pedagogue had difficulty expressing his opinion on the overall climate of the second stage of the selected elementary school. This was mainly due to individual work with some pupils. The respondent often does not come into contact with the whole class. Given the lack of interest of form teachers in his services, he believes that intervention on his part is unnecessary, and thus considers the school climate to be rather positive. However, he stated that there is still room for improvement. It can be assumed that teachers are opposed to maintaining professional contact with the social pedagogue, as they are concerned that he will 'inspect' their classes. This has not been proven by the research. The models above point to the most important dimension - mutual relationships. Relationships appear in each model with a different priority given by the respondents. The aim of the qualitative part of the 
research is not to quantify the conclusions, ${ }^{8}$ but to create the dimensions of the positive climate of the second stage of the elementary school, which are defined and described above.

The following model was created according to the open coding based on the respondents' interviews - the headmaster, form teachers and social pedagogue. It is based on clusters of created codes, which highlight the cooperation between the selected school climate agents and the presented models.

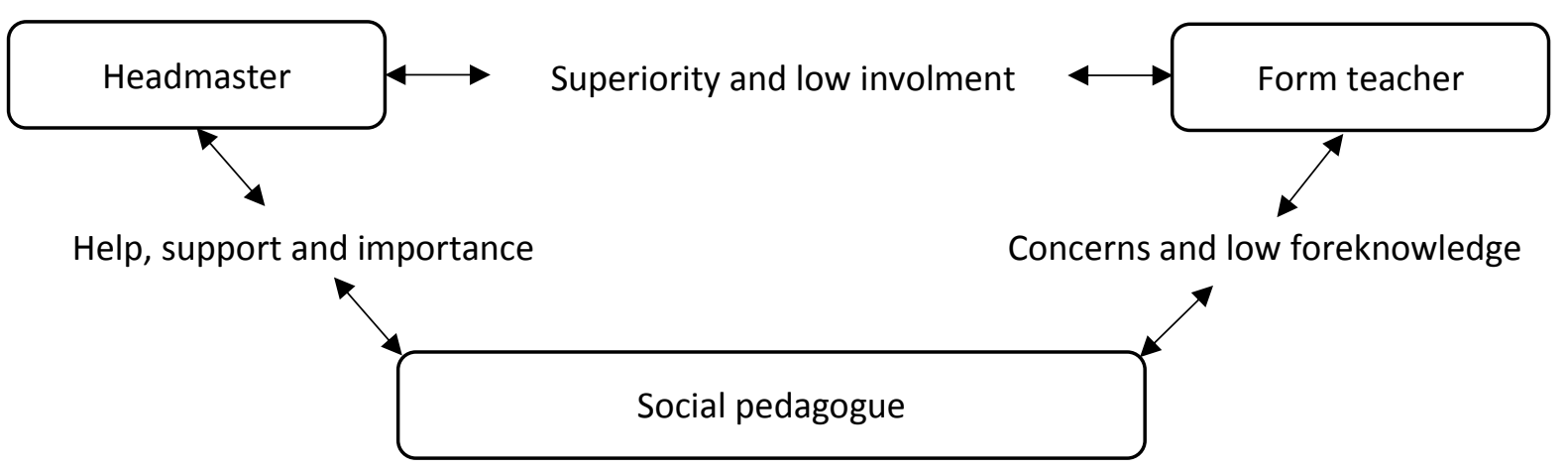

Figure 4 Model of cooperation between the headmaster, form teachers and the social pedagogue

Source: Author.

It is necessary to point out that some cooperation takes place among all respondents (a statement based on the created codes and categories). However, there are some shortcoming. The abovementioned model (Figure 4) is applicable only in one elementary school at the second stage, and moreover, the model is applicable only at a certain time. Cooperation between the headmaster and form teacher can be defined by two terms - superiority and low involvement. The theoretical part of this study describes the headmaster as the highest-ranking agent in the school climate since his actions and handling of situations can influence others, especially those who are lower in the organizational structure. Form teachers perceive the headmaster as an authority. One respondent stated that he visits the headmaster only during consultation hours; the rest of the respondents cooperate with the headmaster when there is a problem. On a positive note, it can be assumed that the teachers are given enough freedom and are thus self-reliant. The form teachers have always found the headmaster helpful, which coincides with the headmaster's statement ...the doors are always open... He is well aware of the teachers' busyness due to teaching and administration. At the same time, he would like them to be more involved, especially in the field of further education of pedagogical staff. On the other hand, the cooperation between the form teacher and the social pedagogue is defined by these terms - concerns and low foreknowledge. It is evident from the form teachers' statements that they do not know much about the job description and services of the social pedagogue. One respondent even said that there is no social pedagogue, nor a counselling centre in the school. Both the social pedagogue and the headmaster stated that teachers were acquainted with the social pedagogue's job description at the meeting. The social pedagogue feels idle in his position, even though he has ideas and a desire to improve work on the school climate. It can be assumed that there is indeed a lack of awareness or lack of interest from teachers since only one respondent appreciated the work of the social pedagogue - his work with a pupil, as well as his work with the whole class. The respondent is well aware of the help and support that the social pedagogue can provide to him and his class. Low foreknowledge may be the reason for their concerns. Teachers do not want to let someone else into their classroom, yet the social pedagogue would welcome greater cooperation from teachers and the ability to work with pupils.

8 This could be considered a mistake in terms of the qualitative part. 
Based on a study by Harpe (2016), where the relationships between teachers were examined, a model of cooperation was created which contains four components. The following components were gradually verified:

- cooperation during working time;

- setting and accomplishing common objectives;

- focus on the result;

- mutual support.

There were no statistically significant differences in Harpe's research (2016), except for the relationship between the evaluation of cooperation among teachers and the pupils' school results. It was stated that pupils' achievements may depend on the level and quality of teachers' cooperation. At the same time, the research confirmed that just one non-cooperating teacher can disrupt the whole school operating concept. That is why the philosophy of the headmaster ...we try to pull together... is perfectly appropriate. Cooperation between the social pedagogue and the headmaster can be seen as help, support and importance; moreover, this cooperation seems to be very promising and positive. The headmaster is vital for the position of social pedagogue, as the headmaster defends the financial side of the social pedagogue's position in front of the school management. He could also create a space for the social pedagogue (which at the moment seems to be insufficient), which could help him to cooperate better with form teachers and their classes. The headmaster perceives the social pedagogue as a help and support for form teachers and pupils. The question is to what extent the headmaster reflects the real cooperation between them. The headmaster is an important and connecting element of the whole model and can significantly influence cooperation among form teachers, and between form teachers and the social pedagogue, and thus contribute to a positive second-stage climate.

\section{Conclusion}

The study describes the current situation of one elementary school in the context of a second-stage climate. Based on the research (the interviews with selected agents), the dimensions of a positive climate were established, and they presented in illustrative models created in Cmap Tools. Each model consists of the respondents' statements from semi-structured interviews. The inspiration for the compilation of these models was the model of positive school climate according to the National School Climate Center from 2017 ("Shared leadership," 2018).

Based on the respondents' statements, a model of cooperation was created that characterizes the cooperation between form teachers, the headmaster and the social pedagogue. The presented process could serve not only for academic purposes but also as an inspiration for teachers and headmasters who focus on the educational process. In practice, we are encountering an increased interest in achieving cognitive goals which arise from the curriculum and strategic documents of the Ministry of Education, Youth and Sports of the Czech Republic. Nevertheless, the interest should be much broader, including an effective level of teaching focused on the relationships between pupils. There should also be interest in communication between teachers, between teachers and pupils, and between teachers and parents. The present procedure is applicable in any school environment where the teacher can adjust interview questions according to his/her own needs. Such an analysis should be followed by a mutual discussion between the teachers about the next intervention proposal, which should be long-term and focused on the results. When analysing the shortcomings resulting from the research, it is possible to identify the following areas: 
- low awareness among teachers about the work of the school counselling centre;

- low awareness of the communication options with the headmaster;

- insufficient interest in further education of pedagogical staff (may result from a small number of offers or one-sided offers);

- the concern of teaching staff about working with other professionals within the classroom climate, and with mutual relationships.

In the context of these points, which could also be supported by quantitatively oriented research, for example concerning pupils at the second stage of the elementary school, a school should set targets for the upcoming period. These points should be brought to the attention of the entire teaching staff, who will take the appropriate position to achieve the objectives. A quantitative approach focused on the role of the social pedagogue in creating a positive climate in primary schools would certainly be fascinating. An endeavour was made at such an investigation by Blaštíková et al. (2015). However, this was mixed research undertaken at primary schools in Slovakia, where the position of social pedagogue is already incorporated into legislation. I believe that elaboration and a more specific methodological grasp would give interesting results.

\section{Declaration of conflicting interests}

No potential conflict of interest is reported by the author.

\section{References}

Act No. 317/2009 Coll., on pedagogical staff and professional staff, as amended [Zákon č. 317/2009 Sb., o pedagogických zamestnancoch a odborných zaměstnancoch a o zmene a doplnení niektorých zákonov]. (2020, March 15). Legislatíva @ MŠVVaŠ SR. Retrieved from https://www.minedu.sk/data/att/2918.pdf

Act No. 561/2004 Coll., on pre-school, primary, secondary, higher vocational and other education, as amended [Zákon č. 561/2004 Sb., o předškolním, základním, středním, vyšším odborném a jiném vzdělávání, ve znění pozdějších předpisů]. (2019, February 2). Documents @ MŠMT. Retrieved from http://www.msmt.cz/dokumenty-3/skolsky-zakon-ve-zneni-ucinnem-od-1-1-2017-do-318-2017

Act No. 563/2004 Coll., on pedagogical staff, as amended [Zákon č. 563/2004 Sb., o pedagogických pracovnících, ve zněná pozdějších předpisů]. (2019, November 17). Documents @ MŠMT. Retrieved from http://www.msmt.cz/dokumenty/aktualni-zneni-zakona-o-pedagogickychpracovnicich-k-1-zari

Adams, C. M., Ware, J. K., Miskell, R. C., \& Forsyth, P. B. (2016). Self-regulatory climate: A positive attribute of public schools. The Journal of Educational Research, 108(2), 169-180. https://doi.org/10.1080/00220671.2014.934419

Anderson, C. S. (1982). The search for school climate: Are view of there search. Review of Educational Research, 52(3), 368-420. https://doi.org/10.3102/00346543052003368

Association of Educators in Social Pedagogy. (2020, February 2). Náplň práce sociálního pedagoga. Retrieved from http://asocped.cz/folders-1305

Blaštíková, L., Grecmanová, H., Nováková, Z., Raszková, T., Skopalová, J., \& Zelinka, J. (2015). Klima školy a jeho ovlivnění školním metodikem prevence a sociálním pedagogem v základní škole. Olomouc: Univerzita Palackého v Olomouci. https://doi.org/10.5507/pdf.15.24448947

Bréda, J., Čapek, R., Dandová, E., \& Kendíková, J. (2017). Třídní učitel jako kouč. Praha: Raabe.

Cameron, C., \& Moss, P. (2011). Social pedagogy and working with children and young people: Where care and education meet. London: Jessica Kingsley. 
Cohen, J., McCabe, E. M., Michelli, N. M., \& Pickeral, T. (2009). School climate: Research, policy, practice, and teacher education. Teachers College Record, 111(1), 180-213.

Creemers, B. P. M., \& Reezigt, G. J. (1999). The role of school and classroom climate in elementary school learning environments. Philadelphia: Falmer Press.

Dalbert, C., \& Stöber, J. (2002). Gerechtes schulklima. In J. Stöber (Ed.), Skalendokumentation persönliche ziele von schülerlnnen (pp. 39-43). Halle, Saale: Martin-Luther-Universität HalleWittenberg.

Dědina, J., \& Odcházel, J. (2007). Management a moderní organizování firmy. Praha: Grada Publishing.

Dewitt, P. M. (2018). School climate: Leading with collective efficacy. London, UK: Sage Publications.

Dicken, M. (2013). Lernen, schulklima und bewegung: Einflussfaktoren, zusammenhänge und wechselwirkungen im lebensraum schule. Saarbrücken: Lap Lambert.

Edgren, G., \& Haffling, A. (2010). Comparing the educational environment (as measured by DREEM) at twe different steges of curriculum reform. Medical Teacher, 32(6), 233-238. https://doi.org/10.3109/01421591003706282

Gillernová, I., \& Krejčová, L. (Eds.). (2012). Sociální dovednosti ve škole. Praha: Grada.

Grecmanová, H. (2003). Klima školy v německé pedagogické literatuře. In S. Ježek (Ed.), Sociální klima školy I (pp. 75-86). Brno: MSD s.r.o.

Grecmanová, H. (2008). Klima školy. Olomouc: Hanex.

Grecmanová, H., Dopita, M., Poláchová Vaštatková, J., \& Skopalová, J. (2012). Klima školy. Soubor dotazníků pro učitele, žáky a rodiče. Praha: Národní ústav pro odborné vzdělávání.

Hamre, K. B., \& Pianta, R. C. (2009). Classroom processes and positive youth development: Conceptualizing, measuring, and improving the capacity of interactions between teachers and students. New Directions for Youth Development, 2009(121), 33-46. https://doi.org/10.1002/yd.295

Harpe, D. (2016). The relationship between teacher collaboration and student achievement (Doctoral dissertation). $\quad$ Retrieved from https://docs.lib.purdue.edu/cgi/viewcontent.cgi?article=1613\&context=open_access_dissertat ions

Hermochová, S. (2009). Jak poznám, jestli jsem dobrý třídní učitel a ve třídě to klape? Retrieved from http://clanky.rvp.cz/wp-content/upload/prilohy/9869/jak_byt_dobry_tridni_ucitel.pdf

Hoy, W. K., \& Hannum, J. W. (1997). Middle school climate: An empirical assessment of organizational health and student achievement. Educational Administration Quarterly, 33(3), 290-311. https://doi.org/10.1177/0013161X97033003003

Hrabal, V. (2002). Sociální psychologie pro učitele. Praha: Karolinum.

Hroncová, J. (2016). Sociálny pedagóg v slovenskej škole v teoretickej reflexii a v praxi. In V. Bělík (Ed.), Možnosti uplatnění sociálního pedagoga/sociální pedagogiky v současné společnosti (pp. 2536). Hradec Králové: Gaudeamus.

Kalnický, J., Malčík, M., \& Uhlař, M. (2012). Obecný management. Ostrava: Repronis.

Kraus, B. (2014). Základy sociální pedagogiky. Praha: Portál.

Lane-Garon, P., Yergat, J., \& Kralowec, Ch. (2012). Conflict resolution education and positive behavioral support: A climate of safety for all learners. Conflict Resolution Quarterly, 30(2), 197-217. https://doi.org/10.1002/crq.21059

Lašek, J. (2001) Sociálně psychologické klima školních tříd a školy. Hradec Králové: Gaudeamus. 
Lašek, J. (2012). Sociálně psychologické klima školních tříd a školy. Hradec Králové: Gaudeamus

Mareš, J., \& Čáp, J. (2007). Psychologie pro učitele. Praha: Portál.

Murphy, J. F., \& Louis, K. S. (2018). Positive school leadership. New York: Columbia University, Teachers College.

National Center on Safe Supportive Learning Environments. (2018, March 3). Welcome! @ Safe Supportive Learning. Retieved from https://safesupportivelearning.ed.gov

Oyetunji, Ch. (2010). The relationship between leadership style and school climate in Botswana Secondary Schools. Saarbrücken: Lap Lambert.

Phillips, S. F., \& Rowley, F. S. (2016). The Tripod School Climate Index: An invariant measure of school safety and relationships. Social Work Research, 40(1), 31-39. https://doi.org/10.1093/swr/svv036

Pinkas, G., \& Bulić, A. (2017). Principal's leadership style, as perceived by teachers, in relation to teacher's experience factor of school climate in elementary schools. Human: Journal for Interdisciplinarity Studies, 7(2), 34-50. https://doi.org/10.21554/hrr.091705

Píšová, M. (2004). Klima školy z pohledu začínajícího učitele. Dvě kvalitativní sondy. Brno: MSD s.r.o.

Quin, D. (2017). Longitudinal and contextual associations between teacher-student relationships and student engagement. Review of Educational Research, 37(2), 345-387. https://doi.org/10.3102/0034654316669434

Ramsey, Ch. M., Spira, A. P., Parisi, J. M., \& Rebok, G. W. (2016). School climate: Perceptual differences between students, parents, and school staff. School Effectiveness and School Improvement, 27(4), 629-641. https://doi.org/10.1080/09243453.2016.1199436

Rudasill, M. K., Snyder, K. E., Levinson, H., \& Adelson, J. L. (2017). Systems view of school climate: A theoretical framework for research. Educational Psychology Review, 30(1), 35-60. https://doi.org/10.1007/s10648-017-9401-y

Shared leadership across contexts. (2018, March 4). Our approach @ National School Climate Center. Retrieved from http://www.schoolclimate.org/climate

Shen, B., McCaughtry, N., Martin, J., Garn, A., Kulik, N., \& Fahlman, M. (2015). The relationship between teacher burnout and student motivation. British Journal of Educational Psychology, 85(4), 519-532. https://doi.org/10.1111/bjep.12089

Stake, R. (2005). Qualitative case studies. In K. D. Norman (Ed.), Qualitative research (pp. 443-466). California: Sage Publications.

Stephens, P. (2013). Social pedagogy: Heart and Head. Bremen: EHV.

Švaříček, R., \& Šed'ová, K. (2007). Kvalitativní výzkum v pedagogických vědách. Praha: Portál.

Tapia, J. A., \& Heredia, B. F. (2008). Development and initial validation of the Classroom Motivational Climate Questionnaire (CMCQ). Psicothema, 20(4), 883-889. Retrieved from http://www.psicothema.com/english/psicothema.asp?ID=3570

Thapa, A., Cohen, J., Guffey, S., \& Higgins-D'Alessandro, A. (2013). A review of school climateresearch. Review of Educational Research, 83(3), 357-385. https://doi.org/10.3102/0034654313483907

The 13 dimensions of school climate measured by the CSCI. (2015, March 5). National School Climate Council and NSCC. Retrieved from https://www.schoolclimate.org/themes/schoolclimate/assets/pdf/measuring-school-climatecsci/CSCIDimensionChart-2017.pdf 
Townsend, L., Musci, R., Stuart, E., Ruble, A., Beaudry, M. B., Schweizer, B., ... Swartz, K. (2017). The association of school climate, depression literacy, and mental health stigma among high school students. Journal of Mental Health, 87(8), 567-574. https://doi.org/10.1111/josh.12527

Trojan, V., Tureckiová, M., \& Trunda, J. (2015). Přístupy k managementu vzdělávání v kontextu České republiky. Praha: Univerzita Karlova.

Walterová, E., \& Greger, D. (Eds.). (2009). Přechod žáků ze základní na střední školu: Pohledy z výzkumů. Brno: Paido.

Warburton, V. E. (2017). Peer and teacher influences on the motivational climate in physical education: A longitudinal perspective on achievement goal adoption. Contemporary Educational Psychology, 51, 303-314. https://doi.org/10.1016/j.cedpsych.2017.08.001

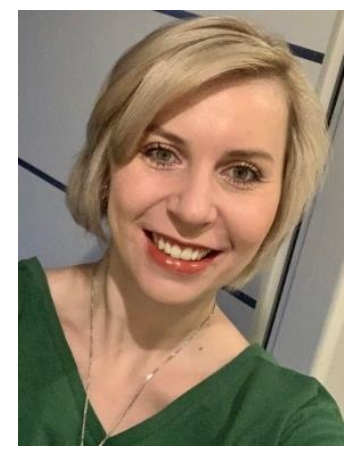

Mgr. Lucie Blaštíková, Ph.D. graduated in Pedagogy - Social Work at the Faculty of Education at Palacký University Olomouc, where she also obtained a doctoral degree in Pedagogy. Since 2015, she has been working at the Department of Pedagogical Sciences at the Faculty of Humanities, Tomas Bata University in Zlín as an assistant professor. As part of her research and publishing activities, Lucie deals with the issue of the climate of primary schools with an emphasis on creating a positive school climate. Her research also focuses on the performance and scope of work of a social pedagogue in primary schools. Pedagogical activity is related to the fields of social policy and social work concerning vulnerable children and their families. Lucie is also the author of a monograph and has participated in a number of domestic and international conferences. 
Supplementary Table 1. Examples of categories, codes and testimony from interviews with the school principal

\begin{tabular}{|c|c|c|}
\hline Categories & Codes & Respondent testimony \\
\hline \multirow{2}{*}{$\begin{array}{l}\text { School counselling service } \\
\text { and social pedagogue... } \\
\text { we have } \\
\text { an advantage! }\end{array}$} & \multirow{2}{*}{$\begin{array}{l}\text { Social pedagogue, school } \\
\text { psychologist, combined } \\
\text { roles, non-teaching staff, } \\
\text { assistance to class teacher, } \\
\text { etc. }\end{array}$} & $\begin{array}{l}\text { "If the class teacher were to do } \\
\text { everything, they wouldn't have time } \\
\text { for anything else." }\end{array}$ \\
\hline & & $\begin{array}{l}\text { "The situation is also negative in terms } \\
\text { of the work catalogue." }\end{array}$ \\
\hline \multirow[t]{2}{*}{$\begin{array}{l}\text { Class teacher - some I } \\
\text { can't move }\end{array}$} & \multirow{2}{*}{$\begin{array}{l}\text { Lack of interest, isolation } \\
\text { of children, we all pull } \\
\text { together, relationship } \\
\text { between teacher and pupil, } \\
\text { trust in teachers, etc. }\end{array}$} & $\begin{array}{l}\text { "Lack of support from parents } \\
\text { and institutions." }\end{array}$ \\
\hline & & "My office is always open." \\
\hline \multirow[t]{2}{*}{$\begin{array}{l}\text { I don't feel a positive } \\
\text { climate }\end{array}$} & \multirow{2}{*}{$\begin{array}{l}\text { Differences between classes, } \\
\text { resolving negative } \\
\text { manifestations, parental } \\
\text { influence, adaptation days, } \\
\text { etc. }\end{array}$} & $\begin{array}{l}\text { "Parents' perception of school } \\
\text { attendance affects climate a lot." }\end{array}$ \\
\hline & & $\begin{array}{l}\text { "The teacher's approach to the } \\
\text { children is markedly reflected } \\
\text { in the classroom." }\end{array}$ \\
\hline \multirow{2}{*}{$\begin{array}{l}\text { Improved school } \\
\text { climate... } \\
\text { yes, but it's... so hard! }\end{array}$} & \multirow{2}{*}{$\begin{array}{l}\text { Co-operation with pupils, } \\
\text { praise and trouble, lack of } \\
\text { support, pupil background. }\end{array}$} & $\begin{array}{l}\text { "...aggressive behaviour, fights, } \\
\text { vulgar swearing." }\end{array}$ \\
\hline & & $\begin{array}{l}\text { "Teachers who do not communicate } \\
\text { do not have good relationships with } \\
\text { pupils." }\end{array}$ \\
\hline
\end{tabular}


Supplementary Table 2. Examples of categories, codes and testimony from interviews with class teachers

\begin{tabular}{|c|c|c|}
\hline Categories & Codes & Respondent testimony \\
\hline $\begin{array}{l}\text { What all goes into the } \\
\text { school climate? }\end{array}$ & $\begin{array}{l}\text { Creating the climate, } \\
\text { supporting the climate, } \\
\text { relationships, teaching staff } \\
\text { climate, etc. }\end{array}$ & $\begin{array}{l}\text { "I perceive co-operation with pupils } \\
\text { as very good." } \\
\text { "After half a year, climate at senior } \\
\text { level is acceptable..." }\end{array}$ \\
\hline $\begin{array}{l}\text { Rules, rules and more } \\
\text { rules... }\end{array}$ & $\begin{array}{l}\text { School philosophy, a fair } \\
\text { approach, setting rules, } \\
\text { consistent application, etc. }\end{array}$ & $\begin{array}{l}\text { "A fair approach to all pupils is } \\
\text { essential." } \\
\text { "They come to me when they feel } \\
\text { wronged... either by fellow pupils } \\
\text { or by teachers." }\end{array}$ \\
\hline $\begin{array}{l}\text { Positive climate } \\
\text { - same approach to } \\
\text { pupils }\end{array}$ & $\begin{array}{l}\text { Accommodating, helping } \\
\text { resolve problems, interest } \\
\text { from teachers, personal } \\
\text { relationship with children, etc. }\end{array}$ & $\begin{array}{l}\text { "I highlight successes, but it's very } \\
\text { difficult. Frequent lack of interest in } \\
\text { anything. I wanted a weekend with } \\
\text { parents." }\end{array}$ \\
\hline $\begin{array}{l}\text { I want a positive climate } \\
\text { in the school, so what } \\
\text { can I do? }\end{array}$ & $\begin{array}{l}\text { Co-operation with school } \\
\text { counselling service, form class } \\
\text { periods, meeting with parents, } \\
\text { community circles, etc. }\end{array}$ & $\begin{array}{l}\text { "Respect for children's opinions, } \\
\text { listening to children, humour." } \\
\text { "A positive climate can be promoted } \\
\text { through discussions with children." }\end{array}$ \\
\hline $\begin{array}{l}\text { Negative climate... } \\
\text { not in my class! }\end{array}$ & $\begin{array}{l}\text { Problems at school, problems } \\
\text { with grades, report cards, new } \\
\text { teacher, etc. }\end{array}$ & $\begin{array}{l}\text { "There is a positive climate in my } \\
\text { class." } \\
\text { "The climate is affected by poor pupil } \\
\text { grades." }\end{array}$ \\
\hline $\begin{array}{l}\text { Role of school principal } \\
\text { - help or threat? }\end{array}$ & $\begin{array}{l}\text { Consulting hours with } \\
\text { principal, administration, } \\
\text { discussions with parents, } \\
\text { similarity of opinions, etc. }\end{array}$ & $\begin{array}{l}\text { "I co-operate with the principal when } \\
\text { a problem occurs." } \\
\text { "I think there is a similarity of opinions } \\
\text { amongst the staff." }\end{array}$ \\
\hline
\end{tabular}


Supplementary Table 3. Examples of categories, codes and testimony from interview with social pedagogue

\begin{tabular}{|c|c|c|}
\hline Category & Codes & Respondent testimony \\
\hline $\begin{array}{l}\text { Smaller problem } \\
\text { - job description }\end{array}$ & $\begin{array}{l}\text { Working with the family, } \\
\text { finding threatened children, } \\
\text { counselling and therapy, social } \\
\text { development and } \\
\text { communication, etc. }\end{array}$ & $\begin{array}{l}\text { "The social pedagogue, alongside the } \\
\text { school counsellor and prevention } \\
\text { worker, helps to prevent social } \\
\text { pathologies in classes and school } \\
\text { groups." }\end{array}$ \\
\hline $\begin{array}{l}\text { The class teacher } \\
\text { is a tricky one }\end{array}$ & $\begin{array}{l}\text { Introducing the job } \\
\text { description of teachers, } \\
\text { commission, interview, } \\
\text { climate amongst staff } \\
\text { - prefer not to assess, etc. }\end{array}$ & $\begin{array}{l}\text { "Little interest in the services of the } \\
\text { social pedagogue from teachers, } \\
\text { as a result of fear, worry and lack of } \\
\text { interest." } \\
\text { "I want to work with teachers too, } \\
\text { but it only sometimes works through } \\
\text { discussions." }\end{array}$ \\
\hline $\begin{array}{l}\text { A positive climate yes, } \\
\text { but I have to get into } \\
\text { the classroom }\end{array}$ & $\begin{array}{l}\text { Group of pupils, it depends } \\
\text { on the teacher, parents not } \\
\text { co-operating, etc. }\end{array}$ & $\begin{array}{l}\text { "I want to work with the teacher on } \\
\text { a form-class period programme so I can } \\
\text { get to know the group of pupils better." }\end{array}$ \\
\hline \multirow[t]{2}{*}{ Principal as support } & \multirow{2}{*}{$\begin{array}{l}\text { Backed by principal, } \\
\text { co-operation in commission, } \\
\text { principal well-informed, etc. }\end{array}$} & $\begin{array}{l}\text { "The principal endeavours to create } \\
\text { a positive climate at our school." }\end{array}$ \\
\hline & & $\begin{array}{l}\text { "Anytime I have turned to the principal, } \\
\text { I have always been listened to, which is } \\
\text { very important to me." }\end{array}$ \\
\hline \multirow[t]{2}{*}{ Pitfalls of position } & \multirow[t]{2}{*}{$\begin{array}{l}\text { Job description, undervalued } \\
\text { position, combination of roles, } \\
\text { finance, low awareness, etc. }\end{array}$} & $\begin{array}{l}\text { "Parents not interested in fulfilling } \\
\text { obligations determined by social } \\
\text { pedagogue." }\end{array}$ \\
\hline & & $\begin{array}{l}\text { "I think the work of a social pedagogue } \\
\text { is undervalued." }\end{array}$ \\
\hline
\end{tabular}

